\title{
FORMULASI EPISTEMOLOGI FRANCIS BACON DAN RENE DESCARTES DALAM TRADISI KEILMUAN ISLAM
}

\author{
Ach. Tijani \\ Institut Agama Islam Negeri (IAIN) Pontianak \\ Email:achtijani@gmail.com
}

\begin{abstract}
Islam and the West are two civilizations that seem to be on two sides facing each other. The West represents progress while Islam represents lagging. Even though these symptoms cannot be categorized in black and white, the Western power in dominating science, technology and politics is at least an indicator of progress. This study starts from this awareness in looking back at the epistemological context of science in Islam and at the same time comparing it with the initial starting point of progress in the West by two pioneers of Western philosophers, Francis Bacon and Rene Descartes. Through philosophical study it was found that the scientific epistemology of Islam must shift from merely the study of the text (bayani), proof of the text (burhani) and pengahayatan text ( $f$ irfani) to cosmological studies as objects of knowledge through empirical phenomena and potential ratio awareness.
\end{abstract}

(Islam dan Barat adalah dua peradaban yang seakan berada pada dua sisi yang berhadaphadapan. Barat merepresentasikan kemajuan sementara Islam merepresentasikan ketertinggalan. Gejala tersebut walau tidak dapat dikategorikan secara hitam-putih, namun kedigdayaan Barat dalam mendominasi ilmu pengetahuan, teknologi dan politik setidaknya menjadi indikator dari sebuah kemajuan. Kajian ini bertolak dari kesadaran tersebut dalam melihat kembali konteks epistemologis keilmuan dalam Islam dan sekaligus membandingkannya dengan titik tolak awal kemajuan di Barat oleh dua pelopor filsuf Barat yaitu Francis Bacon dan Rene Descartes. Melalui telaah filosofis ditemukan bahwa epistemologi keilmuan Islam harus bergeser dari sekedar telaah teks (bayani), pembuktian teks (burhani) dan pengahayatan teks ('irfani) pada kajian kosmologis sebagai obyek pengetahuanmelalui fenomena empiris dan potensi kesadaran rasio).

Kata Kunci: Ilmu, epistemologi, teks, konteks

\section{PENDAHULUAN}

Perkembangan ilmu pengetahuan

telah menghantarkan umat manusia menapaki peradaban yang sangat tinggi.Hasil daya pikir manusia mulai dari teori hingga kemudian menjadi realitas konkret telah merubah wajah dunia menjadi hingar bingar.Saat ini dunia tidak lagi sepi, namun telah dipenuhi oleh karya manusia, berupa tekhnologi yang memudahkan kelangsungan hidup manusia itu sendiri. Sebuah perkembangan menakjubkan, menandakan bahwa manusia benarbenar mampu memposisikan dirinya sebagai pengemban amanah dari 
Ach. Tijani

Formulasi Epistemologi Francis Bacon dan Rene Descartes dalam Tradisi Keilmuan Islam

tuhannya untuk memanfa'atkan dunia dan mengaturnya.

Perkembangan tersebut cukup membuat setiap manusia berbangga dengan hasil karyanya.Namun menjadi sebuah masalah, jika kemudian perhatian ditujukan pada keberadaan kaum muslimin. Di balik memuncaknya peradaban yang begitu mengagumkan, keberadaan kaum muslim hanya sebagai penikmat dari sebuah hasil usaha. Karenanya kaum muslim hanya sebagai konsumen, pada suatu saat bisa saja menjadi korban dibalik kedigdayaan peradaban tersebut. Kebaradaan muslim saat ini, layaknya orang yang tertidur pulas di atas kasur busa empuk yang diiringi dengan mimpi-mimpi indah, namun ketika mimpi berganti dengan kenyataan mereka akan kehilangan keindahan itu. Begitulah ilustrasi keadaan kaum muslim yang terbuai dengan karya orang lain.

Sementara di Barat, mereka dengan penuh semangat terus berpacu mengembangkan daya pikir mereka menuju kedinamisan yang matang. Begitu cukup kentara perbedaan antara Barat yang progresif dengan muslim yang statis dan regresif. Titik inilah menjadi sebuah persoalan yang sedapat mungkin agar terselesaikan secepatnya.

Bila lebih detil mendekati keduanya (Barat-Muslim), secara garis kekayaan konsep, muslim lebih dominan dibandingkan Barat. Salah satu konsep anugerah Tuhan yang tak tergantikan sampai saat ini adalah, Al-Qur'an.Kitab suci ini secara komprehensif mewadahi seluruh aspek kehidupan. Di dalamnya terdapat ayat-ayat yang secara langsung akan terus membimbing manusia ke arah yang semakin sempurna. Hanya saja selama ini kaum muslim cuma bisa mengklaim hasil sebuah olah pikir sebagai bagian dari Al-Qur'an, namun tidak mampu membuktikan secara implisit kedigdayaan Al-Qur'an secara kesatria, dalam artian muslim belum mampu mempersembahkan penemuan monumental kepada dunia. Sehingga, umat muslim cuma bisa berkisar pada pengagungan teks-konseptual tidak pada produktifitas-realistis.

Sejujurnya, kajian ini merupakan bagian dari kecemburuan pribadi penulis terhadap Barat yang dengan serta merta mengungguli muslim. Di pihak yang lain, kajian ini juga berangkat dari kegerahan yang membeku bercampur gemas tehadap dinamika umat muslim 


\section{Al-Hikmah: Jurnal Dakwah, Volume 12, Nomor 2, Tahun 2018 \\ [P. 262-262]}

yang tak kunjung sadar dari kondisi narsisnya. Otensitas Al-Qur'an sering kali membutakan kesadaran kemanusiaannya. Potensi yang berupa rasio dan intuisi kadangkala terhenti pada perbincangan Al-Qur'an sebagai teks suci saja. Padahal yang diharapkan adalah penghubungan teks pada kebutuhan tekhnis-realistis.

Jika mau sejenak merefleksikan keterbelakangan tersebut,maka akan muncul berbagai macam pertanyaan yang menggugah. Salah satu pertanyaan adalah, "kenapa dibalik kekayaan konsep, Islam malah jauh tertinggal oleh Barat?"Maka jawaban sementara pasti ada yang janggal dalam episetemologi keilmuan Islam itu sendiri. Pada sisi inilah kajian ini akan diarahkan.

Bertumpu dari problemmuslim yang menggelikan tersebut, serta keadaan Barat yang mengagumkan dengan seabrek suguhan produknya, perbincangan ini akan terus berlangsung dengan menapaki teori yang diusung oleh Francis Bacon dan Rene Descartes. Keduanya menjadi landasan perbincangan sebagai akibat dari munculnya prakonsepsi penulis yang menempatkan dua tokoh tersebut sebagai tokoh yang representatif dari sekian banyak tokoh
Barat yang ikut andil menyuburkan perkembangan ilmu pengetahuan di Barat.

Berpacu dari hasil pemikian Francis Bacon dan Rene Descartes dalam melihat keterpurukan umat muslim, memungkinkan terjadinya perubahan. Keduanya merupakan tokoh pendobrak kestatisan yang dulu penah terjadi di Barat sekitar abad ke16.Keduanya dinobatkan sebagai tokoh yang muncul sebagai bagian dari gerakan renaisans sekaligus pelopor pendobrak wajah baru dunia menuju ambang kemodernan ${ }^{1}$. Keberadaan muslim saat ini, boleh diandaikan begitu sangat dekat dengan setting sosial dunia Barat pra renaisans tersebut. Berawal dari alasan inilah Bacon dan Descartes dpilih sebagai titik formal dalam menyelesaikan permasalahan yang melilit kaum muslim, seperti yang disinggung di atas.

Secara detil kajian ini akan dirilis melalui beberapa tahapan. Mengawali kajian ini, akan didahului dengan ulasan sejarah dan inti epistemologi yang digagas oleh kedua tokoh tersebut di atas. Kemudian pada tahap kedua akan

${ }^{1}$ F. Budi Hardiman, Filsafat Modern dari Marchiavelli sampai Neietsche (Jakarta: Gramedia Pustaka Utama, 2004) hlm. 7 
Ach. Tijani

Formulasi Epistemologi Francis Bacon dan Rene Descartes dalam Tradisi Keilmuan Islam

disinggung berbagai hal yang berkaitan

dengan epistemologi dan tradisi

keilmuan di tengah-tengah umat muslim.

Ketiga atau tahap terakhir dari kajian ini

berupa penutup yang berisi kesimpulan sebagai sebuah tawaran penyelesaian dari problem yang diangkat.

\section{SEJARAH HIDUP FRANCIS BACON DAN RENE DESCARTES}

Ketika mengulas buah pikiran dua tokoh di atas, maka pembicaraan akan bergulir pada rentetan sejarah Eropa pada abad ke-16. Pada abad tersebut kedua tokoh ini memulai pengembaraan inetlektualnya sebagai bagian dari tokoh filsafat Barat yang mempunyai peran penting dalam pergolakan pemikran dan keilmuan.Untuk mempertegas perannya serta mengulas inti pemikiran dari dua tokoh tersebut maka penguraian historis sepak terjangnya menjadi penting untuk diselami.

\section{Francis Bacon}

Francis Bacon terlahir di London

21 Januari 1561 M. Ayahnya bernama Nicolas Bacon.Riwayat studinya, dia pernah belajar di Trinity College
Cambridge $^{2}$.Kemudian dia juga banyak dikenal sebagai Nabi utama dari revolusi ilmiah dengan berbagai macam penyegarannya di seputar keilmuan. Berbekal pendidikan hukum yang pernah dia peroleh, dia memulai karir politiknya dengan harapan dapat memunculkan idenya untuk kemajuan lmu pengetahuan. Pada akhirnya dia memperoleh posisi strategis dalam percaturan politiknya hingga mendapat gelar kebangsawanan. Pada sisi yang lain, dia juga terkenal sebagai orator tenar di parlemen Inggris serta ahli hukum dan tata Negara ${ }^{3}$.

Meneropong kehidupan Bacon, berarti pada saat yang sama secara tidak langsung akan masuk pada masa pemikiran Barat-Modern tepatnya pada masa awal munculnya renaisans sekitar abad ke-15 dan 16 sebagai upaya melahirkan kembali kebudayaan Yunani kuno ${ }^{4}$. Renainsans yang dimaksudkan pada gerakan yang muncul pada masa Bacon adalah, suatu gerakan yang meliputi suatu zaman di mana orang merasa drinya sebagai orang yang telah

\footnotetext{
${ }^{2}$ Ibid.hlm. 26

3 Lihat http://www.thingsrevealed.net/ dscrtbacn.htm diakses 16 Oktobe 2009

${ }^{4}$ Surajiyo, IlmuFilsafat: Suatu Pengantar, (Jakarta : Bumi Aksara, 2005), hal : 157
} 


\section{Al-Hikmah: Jurnal Dakwah, Volume 12, Nomor 2, Tahun 2018 \\ [P. 262-262]}

dilahirkan kembali dalam keadaban. Manusia pada saat itu digiring untuk kembali pada sumber-sumber murni pengetahuan dan keindahan ${ }^{5}$.

Pada masa ini terjadi beberapa benturan pemikiran.Bisa dibilang pada masa ini disebut sebagai era kebangkitan kembali pemikiran yang bebas dari dogma-dogma agama. Renaisans sebagai simbol peralihan dari kebudayaan Middle Age menjadi kebudayaan modern. Manusia pada saat itu merindukan pemikiran bebas seperti yang pernah mengakar pada masa Yunani Kuno.Letupan transformatif ini ditandai dengan banyaknya penemuanpenemuan teori keilmuan modern.Hal itu sebagai akibat dari suburnya pemikiran progresif di kalangan para ilmuan ${ }^{6}$.

Renaisans yang terdengung di Eropa tersebut kemudian merembes ke tanah Inggris tempat Bacon hidup. Secara tidak langsung Bacon akan ketimpa ciprat dari isu renainsans itu sendiri. Beberapa kritiknya sebagai dampak dari renainsans adalah argumentnya yang menunjukkan

\footnotetext{
5 Harun Hadiwijono, Sari Sejarah Filsafat Barat 2 (Yogyakarta : Kanisisus, 1999) hlm.11

6 Rizal Muntasyir,Sejarah Perkembangan Ilmu dalam Filsafat Ilmu (Yogyakarta: Liberti, 2007)hlm.76
}

kejenuhannya pada filsafat skolastik $^{7}$.Tipe filsafat skolastik banyak dieemban oleh para tokoh pada abad pertengahan.Cirinya yang lebih dekat pada bahasan teologi menjadikan tokohtokoh filsafat di era pertengahan ini lebih dikenal dengan sebutan Ancilla Theologia (abdi agama).Dalam artian lain semua penemuan ilmiah pada era ini diarahkan untuk mendukung kebenaran agama ${ }^{8}$.

Kondisi di atas sangat berlawanan dengan apa yang dipikirkan oleh Bacon. Dia beranggapan bahwa persoalan ilmu pengetahun dan filsafat harus dipisahkan dari persoalan agama.Agama hanya bisa dipahami dengan wahyu, menurutnya kemenangan agama atau iman adalah, ketika dogmadogma agama itu tidak mampu dicerna oleh agama 9 .

Secara priodik-historis, posisi Bacon berada pada deretan tokoh filsafat modern.Namun secara aliran pemikiran, Bacon berada pada deretan tokoh filsafat yang berada pada kubu empirisme ${ }^{10}$.

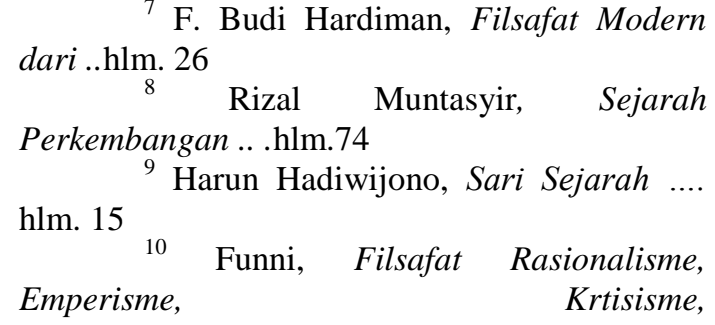


Ach. Tijani

Formulasi Epistemologi Francis Bacon dan Rene Descartes dalam Tradisi Keilmuan Islam

Penempatan lain juga disandarkan

padanya sebagai seorang renaisans, dengan isu pemikirannya yang menggebu-gebu dalam mengusung isu ini $^{11}$.

Penempatan ganda pada Bacon dalam sisi aliran sangat wajar.Pada dimensi konteks waktu, dia menghabiskan umurnya dengan wacana renainsans yang digulirkn di Eropa, Sehingga penempatan ganda berpihak padanya.Secara substansi pemikiran, teorinya berpihak pada kubu empirisme. Adapun yang dimaksud dengan empirisme disini adalah, aliran filsafat yang menyatakan bahwa hakikat dari ilmu pengetahuan berupa pengalaman ${ }^{12}$.

Konkretnya, aliran empirisme sangat bersentuhan dengan interaksi dua unsur, yaitu antara subyek (pengamat) dan obyek (yang diamati). Dua unsur tersebut tidak bisa dinisbikan dalam aliran empirisme. Ada unsur ketiga sebagai konsekwensi dari dua usur dasar tadi yaitu pengalaman inderawi riil

(http://makalah85.blogspot.com/2008/11/filsafatrasionalisme-emperisme.html diakses 17 Oktober 2009)

${ }^{11}$ Lihat lampiran kalsifikasi yang dibuat F. Budi Hardiman Filsafat Modern dari Marchiavelli sampai Neietsche (Jakarta: Gramedia Pustaka Utama,2004).

12 Ali Mudhaffir "Pengenalan Filsafat" dalam Filsafat Ilmu (Yogyakarta: Liberti, 2007)hlm.40 seperti, bersingungan fisik anataran pengamat dan yang diamati pada beberapa kasus tertentu ${ }^{13}$.

Secara detil, Bacon mempunyai perhatian yang besar pada dunia pengetahuan modern. Hal itu dibuktikan dengan beralihnya Bacon dari filsafat tradisional yang hanya terpesona dalam maslah etis yang diusung Yunani, serta juga menyisihkan teologi yang diusung ulang Romawi pada abad pertengahan. Menurutnya perlakuan para filosof pada abad pertengahan yang menempatkan ilmu pengetahuan sebagai abdi dari teologi merupakan kesalahan besar. Sebaliknya Bacon malah menempatkan ilmu pengetahuan merupakan bagian dari sifat qodrati manusia, sekalgus dalam posrsi berikutnya menempatkan manusia sebagai ukuran dai segalanya ${ }^{14}$.

Penempatan manusia sebagai sentral dinamika dari segalanya menguatkan Bacon sebagai seorang empirisme murni.Hal ini kemudian didukung dengan argument lainnya yang menyatakan agar manusia menghindari dari prasangka-prasangka terhadap suatu

13 Louis O. Kattsoff, Pengantar Filsafat, cet.IX(Yogyakarta: Tiara Wacana Yogya,2004) hlm.132-133

dari...hlm. 27

${ }^{14}$ F. Budi Hardiman, Filsafat Modern 


\section{Al-Hikmah: Jurnal Dakwah, Volume 12, Nomor 2, Tahun 2018 \\ [P. 262-262]}

obyek.Akan tetapi metode yang benar menurutnya adalah, mengamati langsung obyek tersebut yang berupa alam semesta, kemudian dilakukan eksperimin-eksperimin.Dari fakta-fakta tersebut kemudian ditarik sebuah ikhtisar. Proses inilah kemudian dalam perkembangan ilmu pengetahuan modern disebut dengan teori induksi ${ }^{15}$.

Teori induksi yang disuguhkan oleh Bacon secara teknis adalah, suatu metode atau suatu proses penyisihan atau pelenyapan, dengannya semua sifat, kemudian yang tidak termasuk sifat yang tunggal dilenyapkan. Tujuannya ialah untuk memiliki sifat-sifatnya yang menonjol dalam fakta yang diamati.Dengan metode ini diharapkan menemukan hukum-hukum yang umum dari semua fakta yang tersajikan ${ }^{16}$.

Walau secara teknis teori induktif ini nampaknya lebih dekat dengan nuansa ilmu alam, akan tetapi pada beberapa persoalan sosial teori ini kemungkinan bisa diterapkan, mengingat fenomena sosial juga tedapat gelaran fakta-fakta kecil yang kadang belum sepenuhnya diselami secara mendalam, terkait keterbatasan dan miskinnya metode.

Untuk mematangkan teori induksinya, Bacon juga mempunyai gagasan termashur lainnya yaitu, konsep “idola”.Idola merupakan unsur atau tradisi yang dipuja-puja seperti berhala. Empat kategori yang temasuk dalam kerangka konsep idola. Pertama, idola tibus (tribus=bangsa), adalah prasangkaprasangka yang dihasilakan oleh pesona tatanan ilmiah yang menjangkiti manusia secara kolektif. Kedua, idola cave (cave = gua), adalah prasangka individual yang berupa mnat-minat pribadi yang mengarahkan cara seseorang dalam melihat dunia.Ketiga,idola fora (fora=pasar), pada pembagian yang ketiga ini diktegorikan sebgai kategori yang berbahaya karena, idola yang ketiga ini berupa kata-kata orang yang diterima begitu saja dan mengiring keyakinan seseorang pada penilaianpenilaian yang tidak teruji. Keempat, idola theatra (theatra = panggung) prasangka yang dibangun oleh konsepkonsep para filsuf yang sejatinya merupakan kenyataan subyektif yang

hlm.15

${ }^{15}$ Harun Hadiwijono, Sari Sejarah .....

${ }^{16}$ Ibid. hlm. 16 
Ach. Tijani

Formulasi Epistemologi Francis Bacon dan Rene Descartes dalam Tradisi Keilmuan Islam

menggiring kesadaran seseorang dalam

mengambil sebuah kesimpulan ${ }^{17}$.

Pengenalan terhadap konsep idola yang ditawarkan oleh Bacon tesebut, sebagai upaya agar teori induktif yang digagasnya dapat diterapkan secara sempurna. Dengan mencampakkan semua ketegori idola yang ada, maka kesimpulan yang didapat melalui teori induktif kemungkinan akan mendekati tingkat valid yang tinggi. Selain daripada itu, penyisihan itu berarti sebuah upaya agar terhindar dari genarlisasi gegabah dari setiap fakta ${ }^{18}$.

Secara garis besar dapat disimpulkan tawaran Bacon dalam sumbangsih di bidang epistemologi yaitu, berupa teori induktif dan pola pemikirannya yang bersifat empiris.Artinya, ilmu pengetahuan bisa didapat dari interaksi pengamat (subyek) dan yang diamati (obyek) dengan metode pengambilan kesimpulan yang bermula dari fakta-fakta kecil lalu kemudian ditarik genaralisasi (induktif) dengan pola yang sangat hati-hati lewat penyisihan konsep idola yang dikenalkannya di atas.

\footnotetext{
dari...hlm. 28-29

17 F. Budi Hardiman, Filsafat Modern

${ }^{18}$ Ibid. hlm. 30
}

$\begin{array}{rrr}\text { Secara } & \text { gamblang } & \text { dapat } \\ \text { disimpulkan } & \text { epistemologi } & \text { yang }\end{array}$
ditawarkan oleh bacon adalah: Pertama sumber pengetahuan adalah pengalaman empiris dan fenomenan-fenomena alam. Sedangkan hakikat pengetahuan adalah pengetahuan tentang alam (apoterisori).Kedua instrument untuk mendapatkan pengetahuan adalah indra. Ketiga cara memeperolehnya melalui observasi-ekprimentasi, didata dalam table positif dan negative dan kemudian digenaralisasi ${ }^{19}$.

Apa yang ditawarkan oleh Bacon merupakan embrio dari perkembangan pengetahuan modern. Sampai saat ini, teori induktifnya menjadi salah satu metode yang terus digunakan dalam mengungkap varian pengetahuanpengetahuan modern lainnya.

\section{Rene Descartes}

Rene Descartes terlahir di La Haye Totiraine, sebuah daerah kecil di Perancis tepatnya tanggal 31 Maret 1598.Sejak kecil sudah ditinggalakan ibunya, peristiwa ini kemudian membekali dirinya menjadi seorang yang selalu bersifat khawatir di

19 Alim Ruswantoro, Farncis Bacon (slide mata kuliah program pasac sarjana UIN Sunan Kalijaga, 2009) 


\section{Al-Hikmah: Jurnal Dakwah, Volume 12, Nomor 2, Tahun 2018 \\ [P. 262-262]}

kemudian hari. Pernah studi formal di Coollege des Jessuites de la Fleche pada bidang studi logka, filsafat matematika dan fisika ${ }^{20}$.

Selain dari pada itu, Descartes menjalani hidupnya dengan berpindahpindah melintasi Negara-negara di sepanjang gelaran benua Eropa. Swiss, Belanda, Italia dan Swedia sebagai tempat terakhir sebelum akhirnya menghembuskan nafas tekahir pada tanggal 11 Februari 1650. Walau meniggal di Swedia kemudian tengkoraknya dipindah ke Negara asalnya pada tahun 1667 di Museum d'Histoire Naturelle Paris ${ }^{21}$.

Jika melirik karyanya, Descartes mempunyai karya besaryaitu,Discourse on Method (1637) yang ditulis dalam bahasa Prancis dengan gaya penulisan yang menarik perhatian di zamannya. Menyusul berikutnya yang berjudul Meditations of First Philosophy, terbit tahun 1644 dan Passion of the Soul tahun $1649^{22}$.

20 Zubaedi dkk, Filsafat Barat (Yogyakarta: Ar-Ruz Media, 2007),hlm.17

${ }^{21}$ Ibid.hlm.18

${ }^{22}$ Zainal Arifin Tandjung, Sejarah Singkat Filsafat Modern: Dari Descartes Sampai Wittgenstein, (Jakarta: PT. Pantja Simpati, 1986), hlm. 31
Pada episode berikutnya, Rene Descartes diposisikan sebagai bagian dari tokoh filsafat Modern,bahkan Descartes dinobatkan sebagai pelopor dan pendiri filsafat Modern. Penyebutan filsafat modern yang dinisbatkan pada dirinya merupakan adanya kekhasan yang terdapat dalam pemikrannya. Sedangkan penyebutan modern dan filsafat abad pertengahan bukan pada dikotomi maju dan mundur, akan tetapi bisa dilihat diri cri khas yang dibawa oleh masing-masing kubu. Filsafat abad pertengahan bercirikan sinkretasi antara akal dengan wahyu serta antara rasio dengan agama.Adapun cirri filsafat modern adalah, perhatian khasnya yang cukup antusias tehadap sesuatu yang sifatnya konkret, seperti alam semesta, manusia, hidup bermasyarakat dan $\operatorname{sejarah}^{23}$.

Setelah penobatannya sebagai Bapak Filsafat modern, diakui bahwa Descartes sering mengajukan beberapa pertanyaan yang jawabannya sama pentingnya denga pertanyaannya. Descartes merefleksikan skeptisisesme yang mendalam. Skeptisisme yang mendalam tersebut berupa keraguan

${ }^{23}$ Juaya S. Praja, Alira-aliran Filsafat \& Etika (Jakata: Kencana, 2008) hlm.92 
Ach. Tijani

Formulasi Epistemologi Francis Bacon dan Rene Descartes dalam Tradisi Keilmuan Islam

seorang individu terhadap realitas untuk mengetahui hakikat yang terselubung di dalamnya ${ }^{24}$.

Seperti halnya para filosof para pendahulunya, Descrates mampu merefleksikan keadaan sekitarnya menjadi buah pikir yang monumental. Kehidupannya yang bersinggungan dengan kaum borjuis serta pola hidupnya yang melancong seperti yang terdeskripsikan di atas, Descartes terus menggulirkan pikirannya, sehingga akhirnya mencapai sebuah metodis baru dalam dunia filsafat.

Tangga pertama isi dari buah pikirannya adalah, berupa konsep kesangsian seperti yang tertulis di atas sebagai model aliran skeptisisme. Menurutnya titik kepastian bisa digapai setelah melalui kesangsian. Semakin seseorang menyangsikan segala sesuatu, entah orang tersebut benar-benar dalam keadaan tertipu atau tidak, termasuk menyangsikan bahwa seseoang itu menyangsikan, maka orang tersebut akan semakin ada (exist). Descartes membahasakan kesangsian tesebut berupa ungkapannya yang berbunyi

24 Lihat Reza tonius http://rezaantonius.multiply.com/journal/item/108 diakses 11 Oktober 2009
"Menyangsikan adalah berfikir, maka kepastian akan eksitensiku dicapai dengan berfikir.Maka, "aku berfikir maka aku ada" (cogito ergo sume $)^{25}$.

Melalui statemen cogito ergo sume inilah banyak orang mengenal Descartes.Cara berfikir yang bertolak dari kesangsian tersebut tidak membatasi obyek apapun yang harus diragukan, termasuk Tuhan sekalipun. Menyangsikan bukan berarti mengkhayal, tapi merupakan makna implisit dari sebuah kenyataan. Terus melakukan kesangsian, berarti pada saat yang sama pemburuan akan eksistensi terus bergulir.

Menempatkan seluruh kepastian berada setelah kesangsian yang dikobarkan dalam diri, berarti pada saat yang sama Descartes menempatkan diri sebagai sumber dari segala kepastian itu sendiri. Penegasan ini kemudian tercemin lewat beberapa pernyataannya yang lain berupa rumusan adanya ide bawaan yang terdapat pada masingmasing individu. Ide bawaan tersebut dibahasakan oleh Descartes sebagai butir-butir kebenaran yang secara natural ada.Seluruh pengetahuan bersumber dari ide bawaan ini, namun bukan berarti ide-

${ }^{25}$ F. Budi Hardiman, Filsafat Modern dari... hlm.38 


\section{Al-Hikmah: Jurnal Dakwah, Volume 12, Nomor 2, Tahun 2018}

[P. 262-262]

ide bawaan ini sudah ada dalam pikiran bayi sebagai sebuah ide yang jelas. Ide itu hanya berupa potensi yang dapat diproduksi pada suatu kesempatan yang dihadapkan pada pengalaman, potensi itu secara reflek akan mulai bekerja dan menghasilkan sebuah ide konkret ${ }^{26}$.

Dari penuturan yang runut itulah kemudian ada penjelasan lebih rinci mengenai makna "aku berfikir maka aku ada". Potensi berifikir merupakan suatau pengetahuan langsung yang disebut sebagai pengetahuan filsafat yang pertama.Berfikir merupakan substansi yang tidak memerlukan ruang dan waktu dan tentunya sangat jauh dari sifat bendawi ${ }^{27}$.Dengan meletakkan akal sebagai sebuah pusat dari kesadaran, maka kemudian Descartes ditempatkan sebagai Bapak rasionalisme.Desarctes memahami bahwa, akal budi sebagai jenis perantara khusus untuk mengenal kebenaran serta pemahamannya yang kedua menyatakan bahwa, deduktif merupakan sebuah tekhnik untuk menemukan kebenaran tersebut ${ }^{28}$.

${ }^{26}$ Zubaedi dkk, Filsafat Barat....,hlm. 26

27 Harun Hadiwijono, Sari Sejarah ... hlm. 21

${ }^{28}$ Louis O. Kattsoff, Pengantar .... hlm.
Selain daripada epistemolgi yang dituturkan di atas, Desartes mempunyai pandangan dualistis dalam memandang manusia.Menurutnya, manusia terdiri dari dua substansi yang berbeda yakni jiwa (ruh) dan materi (badan jasmaniah). Susunan substansi inilah yang membedakan antara manusia dan hewan. Pandangan antropologis Descartes ini berujung pada sebuah kesimpulan bahwa jiwa menjadi kendali semua gerak dinamika manusia ${ }^{29}$.

Secara konkret gagasan dapat disimpulkan sebagai barikut :pertama hakikat pengetahuan adalah pemikiran yang lahir dari pemikiran rasional dan sumber pengetahuan adalah akal manusia. Selain itu akal juga ditempatkan sebagai instrument utama dalam menggapai pengetahuan ${ }^{30}$.

Uraian singkat di atas menuntun penulis pada tahap penyimpulan bahwa, epistemologi Descartes dalam menggapai pengetahuan bertolak dari akal sebagai titik sentral dari semua pengetahuan. Hal itu dimulai dengan teori kesangsian sehingga pada saat yang

\section{dari...hlm.40}

${ }^{29}$ F. Budi Hardiman, Filsafat Modern

${ }^{30}$ Alim Ruswantoro, Rene Descartes (slide mata kuliah program pasac sarjana UIN Sunan Kalijaga, 2009) 135. 
Ach. Tijani

Formulasi Epistemologi Francis Bacon dan Rene Descartes dalam Tradisi Keilmuan Islam

sama teori ini menjadi pola pikir yang kemudian dikenal dengan pola pikir deduktif. Untuk itulah aliran pemikiran Descartes adalah rasionalisme serta metode berfikirnya adalah deduktif.

\section{Formulasi Epistemologi Francis}

\section{Bacon Dan Rene Descartes Pada}

\section{Tradisi Keilmuan Islam}

Setelah mengurai panjang mengenai epistemologi yang ditawarkan oleh dua tokoh filsafat modern di atas.Maka kemudian sampailah pada titik aplikatif dan penerapannya. Dalam hal ini penulis mencoba mensinkronkan atau hanya pada taraf menanmbal saja dari beberapa kekurangan metodologi yang selama ini telah digunakan oleh kalangan umat muslim. Hal itu dimaksudkan sebagai salah satu tawaran solotif penyelesaian problem yang tersuguhkan pada titik permulaan kajian ini.

Sifat kajian ini yang hanya berupa tawaran solusi, menyadarkann penulis akan munculnya beberapa tanggapan balik terhadap kajian ini. Sangat wajar, karena sebuah persoalan akan memunculkan berbagai macam komentar dan reflek yang beraneka dari masing-masing individu. Perbedaan ataupun kesamaan merupakan keniscayaan memungkinkan untuk beranjak pada titik kesempurnaan. Selanjutnya penulis akan menyuguhkan sekilas tradisi keilmuan Islam yang selama ini bergulir. Hal itu sebagai bahan acuan untuk menformulasikan penyegaran baru pada tradisi keilmuan muslim.

\section{Sekilas dinamika keilmuan Islam}

Seperti pada titik permulaan kajian ini berlangsung bahwa, kaum muslim menjadi komonitas konsomtif dari produk yang dihasilkan oleh orang di luar muslim (Barat). Kenyataan yang menempatkan kaum muslim sebagai pemilik berjuta teori yang tersurat dalam kitab sucinya yaitu al-Qur'an, pada realitasnya tidak bisa menghantarkan muslim sebagai tonggak dari dinamika peradaban dunia. Ayat-ayat Allah dalam kitab suci hanya diterjemahkan sebagai teks langit yang tidak bisa menggiring umat muslim sebagai umat yang produktif.

Dari realitas tersebut, kemudian menjadi penting untuk dieksplorasi mengenai dinamika dan tradisi keilmuan di tengah-tengah kaum muslim. Karena realita yang ditunjukkan oleh dunia 


\section{Al-Hikmah: Jurnal Dakwah, Volume 12, Nomor 2, Tahun 2018 \\ [P. 262-262]}

muslim tersebut sangat terkait dengan pola dan tradisi keilmuan. Kemungkinan pada sisi tradsi inilah akan ditemukan akar persoalan dari ketertinggalan dan mengekornya umat muslim pada dunia Barat.

Membongkar sebuah dinamika pemikiran, berarti secara tidak sengaja juga akan menyentuh sejarah. Karena, pada hakikatnya tradisi pemikiran tidak akan lepas dari diterminan historisnya. Secara garis besar dterminan yang melingkupi tradisi keilmuan Islam dapat dipilah menjadi dua bagian besar : bangsa Arab dan bangsa-bangsa yang ditaklukkan bangsa Arab. Diterminasi itu mempunyai dampak yang cukup besar pada perkembangan tradisi yang mengalir di lingkungan umat muslim. Misalnya, beberapa kalangan sulit untuk membedakan antara Islam dan Arab itu sendiri, hal yang demikian dipicu dengan gerakan Arabisasi (at-Ta'rib) yang dikonversi pada tubuh Islam itu sendiri $^{31}$. Gerakan ini merupakan gerakan poitik yang tidak dusadari oleh kebanyakan kaum muslim.

\footnotetext{
${ }^{31}$ dikutip oleh Mahmud Arif dari Abd. Mun'im Majid "Tarikh al-Hadharah alIslamiyah fi al-Ushural-Wustha" dalam Pendidikan Islam Transfomatif (Yogyakarta: LKiS Pelangi Aksara,2008) hlm.28
}

Bermula dari gerakan At-Ta'rib inilah bermula transformasi tradisi secara brutal pada bangsa-bangsa non Arab, kemudian pada titik klimaksnya menjadi sebuah problem yang melilit kaum muslim dalam hal dinamika. Determinasi tersebut merembes pada taradisi keilmuan Islam yang termanifestaskan dalam bentuk pewarisn tradisi kuno (al-mauruts al-qodim) secara mentah tanpa diikuti oleh sikap kritis.Realitas keilmuan Islam pun bagaikan telur di ujung tanduk atau berada pada taraf kestatisan (harakat I'tmad $\left.^{32}\right)$.

Fenomena tersebut di atas jika diseret pada realiitas kekinian maka akan muncul anomali-anomali pada tradisi keilmuan muslim. Dianggap kurang nomal karena, yang dominan pada tradisi keilmuan keislaman hanya pada satu epistemlogi yaitu epistemologi bayani. Hal ini sebagai akibat arabisasi tadi yang terlalu dipaksakan sebagai bagian dari tubuh Islam itu sendiri.

Menurut Hasan Hanafi, keilmuan Islam sebagai warisan intelektual yang sampai kepada umat saat ini dapat diklasifikasikan menjadi tiga macam :

32 Mahmud Arif, Pendidikan Islam Transfomatif (Yogyakarta: LKiS Pelangi Aksara, 2008) hlm. 29 
Ach. Tijani

Formulasi Epistemologi Francis Bacon dan Rene Descartes dalam Tradisi Keilmuan Islam

keilmuan naqli muni, naqli-'aqli dan 'aqli murni. Namun pada kenyataannya yang merembes dan menjadi kesadaran pada diri umat muslim hanya didominasi oleh keilmuan yang naqli murni saja. Sedangakan yang 'aqli murni tersisihkan oleh ilmu-ilmu keagamaan.Gejala ini sangat berkaiatan dengan bergesernya kecenderungan umat dari ilmu flsafat, bahkan diangapnya sebagai bagian dari ilmu-ilmu asing ${ }^{33}$.

Sebagai contoh akibat riil dari fenomena di atas adalah, keberadaan Islam yang sangat terbelakang di penghujung peradaban dunia. Di antara Negara-negara Muslim dunia , belum satu pun yang dapat dikategorikan ke dalam Negara industry, paling banter disebut sebagai Negara yang sedang membangun (developing countries) ${ }^{34}$. Menunjukkan bahwa, dalam produktifitas konkret, keberadaan muslim masih sangat jauh dari perkembangan Barat yang tak terjangkau.

Selanjutnya, kembali pada perbincangan mengenai tradisi keilmuan Islam, kemandegan keilmuan Islam

\footnotetext{
${ }^{33}$ Ibid.hlm124

34 Dawam Rahardjo "Krisis Pradaban Islam" dalam,Bayang-bayang Fanatisisme, (Jakarta: Pusat Studi Islam dan Kenegaraan Universitas Paramadina, 2007)hlm.23
}

sangat tergantung pada epistemologi yang digunakan dalam memahami wahyu Tuhan. Kalau melihat skema konstruk epistemologi, paling tidak umat muslim mengenal tiga epistemologi yang sudah akrab yaitu, bayani, burhani dan 'irfani. Nah, menjadi tidak seimbang ketika memilih satu epistemologi dan mengingkari epistemologi lainnya. Seperti yang dibahasakan penulis di atas, sebagai bentuk anomali yang belum disadari oleh kaum muslim. Bukan tanpa alasan memasukkan semua epistemologi tesebut sebagai keutuhan yang saling menunjang dari kekurangan epistemologi lainnya. Misalnya, bayani yang hanya berkisar pada qiro'ah nash (pembacaan teks saja) dan limitnya hanya menjangkau pengetahuan biasa (ordinary knowledge). Epistemologi Burhani sedikit lebih membuka ruang bagi rasio untuk mensintesiskan antara qio'ah nash dan serapan wacana serta fenomena yang dapat diatangkap oleh akal. Pada epistemologi buhani ini sudah menjangkau pengetahuan sains (scientific knowledge).Kemudian pada epistemologi yang terakhir yaitu 'Irfani 


\section{Al-Hikmah: Jurnal Dakwah, Volume 12, Nomor 2, Tahun 2018}

[P. 262-262]

yang menjangkau pengetahuan metafisik (Metascience) $)^{35}$.

Kemudian yang mengekang kedinamisan kaum muslim mencapai puncak peradaban adalah, otoritas kebenaran yang dilebelkan pada satu titik saja. Misalanya mengakarnya doma di kalangan umat muslim bahwa kitab suci (al-Qur'an) sebagai otoritas kebenaran yang tidak bisa tersentuh (untucheble). Hal ini jika dikaitakan dengan analisis Hasan Hanafi seperti yang telah diurai sebelumnya, merupakan realitas dari mengakarnya warisan naqli murni. Umat muslim terasa lupa bahwa al-quran itu sendiri mempunyai makna yaitu, sebagai teks langit (berupa ajaran keagamaan) tapi di sisi lain merupakan teks bumi (berupa ajaran kemanusiaan) $)^{36}$.

Demikian sekelumit tinjauan tradisi keeilmuan serta epistemologi yang selama ini digunakan oleh para cendikiawan muslim. Pencapaian kebenaran yang diraih oleh para cendikiawan muslim belum mampu

\footnotetext{
${ }^{35}$ Mahmud Arif, Pendidikan Islam ... hlm. 257

36 Zuhairi Misrawi "Wawasan baru Islam: Kado Peikiran untuk Mas Dawa". dalam Demi Toleransi Demi Pularisme, (Jakarta: Paramadina, 2007) hlm.403
}

memupuk semangat kaum muslim untuk produktif. Hal itu memang sangat terkait dengan berbagai hal, mulai dari determinasi politik dan epistemologi yang timpang.

\section{Penerapan teori Bacon dan Descartes}

Setelah mengurai dengan singkat tradisi keilmuan Islam, nampak beberapa aspek yang perlu mendapat pelurusan, guna menciptakan umat yang produktif dan dinamis.Secara garis besar, epistemologi yang dibangun oleh Bacon dan Decartes (Empiris dan rasio) secara natural telah tecipta dalam tradisi keilmuan Islam.Hal itu terungkap dengan adanya tiga epistemologi yang dikenal dalam dunia Islam.

Pernyataan di atas bukan berarti menempatkan epistemologi keilmuan Islam bebas kritik dan kekurangan. Sebagai tanda adanya kekurangan dalam epistemologi tersebut adalah mandulnya epistemologi tersebut dalam menyuguhkan karya yang monumental pada peradaban dunia.Salah satu hal yang bisa ditambahkan dari pemikiran Bacon pada tradisi pemikiran Islam adalah, konsep idola yang harus mendapatkan porsi lebih besar pada setiap pencarian pengetahuan.Kalau ditinjau dari sudut 
Ach. Tijani

Formulasi Epistemologi Francis Bacon dan Rene Descartes dalam Tradisi Keilmuan Islam

ini, Islam begitu sangat narsis dan memberhalakan tradisi dan kelompok. Dalam konsep Bacon, pengetahuan itu akan benar-benar tergapai secara murni jika dari empat aspek idola (bangsa,pasar,diri orang lain) itu disisihkan.

Selanjutnya jika dikaitkan dengan konsepnya Descartes sisi yang harus dibenahi adalah pada sikap yang kritisnya. Dalam hal ini, menyangsikan serta keberanian berfikir secara bebas tentang segala hal lewat mempertanyakannya, masih sangat minim digunakan oleh umat muslim dalam mencari pengetahuan, sehingga polanya adalah pengulangan atau egrresif. Pada sisi inilah pemikiran Descartes lewat konsepnya "aku berfikir maka aku ada" perlu mendapat porsi yang layak pada epistemologi keilmuan Islam.

Pada dua sisi ini saja yang bisa ditangkap oleh penulis sebagai pembenahan terhadap epistemologi yang sudah ada.Artinya penulis tidak seluruhnya menyisihkan epistemologi yang ada dalam keimuan Islam, tetapi hanya mengambil yang sinkron dari hasil pemikiran Bacon dan Descartes untuk dtambahkan pada sisi yang kurang.

\section{KESIMPULAN}

Tergelar sudah uraian singkat dari kajian yang berangkat dari kegerahan dan ketertinggalan muslim dengan melandaskan pada pegkajian pemikiran tokoh. Dari semua yang telah tersuguhkan pada tulisan ini, maka kemudian sampailah pada kesimpulan terakhir sebagai klimaks dari kajian ini.

Dalam epistemologi keilmuan Islam pemberhalaan tehadap apapun, baik itu tehadap kelompok, individu, wacana publik serta pemikiran tokoh harus disisihkan, beralih pada metode induktf dengan melibatkan langsung penginderaan (empiric) pada obyek yang menjadi pokok perhatian atau bahasan. Dalam hal ini merupkan sumbangsih dari Bacon.

Sumbangan Descartes adalah, dalam epistemologi keilmuan Islam semestinya semua wacana dan kebenaran yang tersuguhkan harus kembali dipersoalkan tanpa membatasi pada batasan apapun, dengan harapan agar muncul nantinya eksistensi baru atau pengetahuan baru. 
[P. 262-262]

\section{DAFTAR PUSTAKA}

Ali,Ihsan dkk Demi Toleransi Demi Pularisme, Jakarta: Paramadina, 2007

Arif,Mahmud, Pendidikan Islam Transfomatif, Yogyakarta: LKiS Pelangi Aksara, 2008

Dosen Filsafat UGMFilsafat Ilmu Yogyakarta: Liberti, 2007

Hakim,Abd, Bayang-bayang Fanatisisme, Jakarta: Pusat Studi Islam dan Kenegaraan Universitas Paramadina, 2007

Hadiwijono, Harun, Sari Sejarah Filsafat Barat 2 Yogyakarta: Kanisisus, 1999

Hardiman, F.Budi, Filsafat Modern dari Marchiavelli sampai Neietsche, Jakarta: Gramedia Pustaka Utama, 2004

Kattsoff, Louis O. ,Pengantar Filsafat, cet.IXYogyakarta: Tiara Wacana Yogya, 2004

Muntasyir,Rizal,Sejarah Perkembangan Ilmu dalam Filsafat Ilmu, Yogyakarta: Liberti, 2007).

Praja, Juaya S. ,Aliran-aliran Filsafat \& Etika Jakata: Kencana, 2008

Ruswantoro, Alim, Farncis Bacon, Materi kuliah tema-tema epistemologi program pasca sarjana 2009

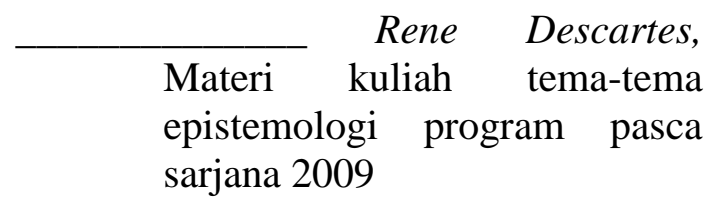

Surajiyo, IlmuFilsafat: Suatu Pengantar, Jakarta: Bumi Aksara, 2005

Tandjung,Zainal Arifin,Sejarah Singkat Filsafat Modern: Dari Descartes Sampai Wittgenstein, Jakarta: PT. Pantja Simpati, 1986

Zubaedi dkk, Filsafat Barat ,Yogyakarta: Ar-Ruz Media, 2007

Funni, Filsafat Rasionalisme, Emperisme, Krtisisme, (http://makalah85.blogspot.com /2008/11/filsafat-rasionalismeemperisme.html diakses 17 Oktober 2009)

http://www.thingsrevealed.net/dscrtbacn. $\underline{\mathrm{htm}}$ diakses 16 Oktobe 2009

Reza tonius http://rezaantonius.multiply.co $\underline{\mathrm{m} / \text { journal/item/108 diakses } 11}$ Oktober 2009 
Ach. Tijani

Formulasi Epistemologi Francis Bacon dan Rene Descartes dalam Tradisi Keilmuan Islam 